\title{
Novel Washing Methods to Extend the Quality and Enhance the Nutritional Value of Minimally Processed Vegetable Products
}

\author{
Ana Belen Martin-Diana \\ Technological University Dublin, anabelen.martindiana@tudublin.ie \\ Daniel Rico \\ Technological University Dublin, daniel.rico@tudublin.ie \\ Jesus Maria Frias \\ Technological University Dublin, Jesus.Frias@tudublin.ie
}

See next page for additional authors

Follow this and additional works at: https://arrow.tudublin.ie/tfschafart

Part of the Food Science Commons

\section{Recommended Citation \\ Martin-Diana, A. B., Rico, D., Frias, J., Mulcahy, J., Henehan, G. T. M. and Barry-Ryan, C. Novel Washing Methods to Extend the Quality and Enhance the Nutritional Value of Minimally Processed Vegetable Products. Acta horticulture, 687, 2005. DOI: 10.21427/d7346s}

This Article is brought to you for free and open access by the School of Culinary Arts and Food Technology at ARROW@TU Dublin. It has been accepted for inclusion in Articles by an authorized administrator of ARROW@TU Dublin. For more information, please contact arrow.admin@tudublin.ie, aisling.coyne@tudublin.ie, gerard.connolly@tudublin.ie.

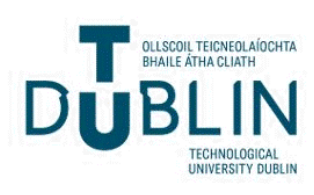




\section{Authors}

Ana Belen Martin-Diana, Daniel Rico, Jesus Maria Frias, Jemina Mulcahy, Gary Henehan, and Catherine Barry-Ryan 


\title{
Novel Washing Methods to Extend the Quality and Enhance the Nutritional Value of Minimally Processed Vegetable Products
}

\author{
Ana Belen Martín-Diana, Daniel Rico, Jesus M. Frías, Jemina Mulcahy, \\ Gary T.M. Henehan and Catherine Barry-Ryan \\ School of Food Science and Environmental Health, Postharvest Unit \\ Dublin Institute of Technology (DIT), Cathal Brugha Street \\ Dublin 1, Ireland
}

Keywords: salad-cut lettuce, sliced carrot, Ca-lactate, O3, whey permeate

\begin{abstract}
This paper reports on the development of alternative washing treatments to extend the quality and safety of fresh cut-vegetables and improve their nutritional value. Washing with Ca-lactate $(3 \%)$ prevented the bleaching effect on salad-cut lettuce and sliced carrots and the appearance of whiteness on the second one normally associated with sodium hypochlorite washing solutions (120 ppm Chlorine). Ca-lactate maintained and enhanced nutritional values during storage, especially in carrots. Sliced carrots treated with Ca-lactate had significant $(p<0.05)$ higher levels of carotenoids (antioxidant capacity) than Chlorine treated carrots at the end of 10-day storage. Also, ascorbic acid content was significantly $(p<0.05)$ higher in samples treated with Ca-lactate than in Chlorine-treated lettuce and carrots. Optimisation studies of Ca-lactate treatments showed high temperature $\left(50^{\circ} \mathrm{C}\right)$ at the studied range of concentrations $(0.5-3 \%)$ significantly $(\mathbf{p}<0.05)$ reduced PPO- and POD-mediated browning in salad-cut lettuce when compared with $4^{\circ} \mathrm{C}$ and $25^{\circ} \mathrm{C}$ treatments. Washing solution containing dissolved $\mathrm{O}_{3}$ at $25^{\circ} \mathrm{C}$ was compared with Ca-lactate solution at $50^{\circ} \mathrm{C}$. Samples treated with $\mathrm{O}_{3}$ (alone and combined with Ca-lactate at $5^{\circ} \mathrm{C}$ ) had significantly lower PPO values than Ca-lactate treated samples. Whey permeate $(0.5-3 \%)$ washing treatments significantly $(p<0.05)$ reduced the levels of PPO and POD activity in salad-cut lettuce and sliced carrots when compared with Chlorine treatment. The alternative washing treatments tested showed good quality retention and microbial loads in the processed vegetables and maintained the nutritional value as good as or better than Chlorine treatment.
\end{abstract}

\section{INTRODUCTION}

The fresh-cut produce industry represented $\$ 10$ to $\$ 12$ billion in 2000 in the United States (Garret, 2002) and the production in Ireland amounts to approximately $€ 300$ million per annum (An Bord Glas, 2002). Chlorine solutions (50-200 mg/L) are widely used to wash fruit and vegetables, however the possible formation of carcinogenic chlorinated compounds in water (chloramines and trihalomethanes) has called into question the use of chlorine in food processing plants (Wei and col., 1999). There is a real need to find new alternatives for preservation of minimally processed vegetables in order to maintain the quality attributes after the processing. Thus, there is huge interest in developing alternative washing treatments for fresh cut vegetables.

Ca-lactate is reported to maintain firmness by crosslinking with cell wall and middle lamella pectins in plants (reference). Thus, fruit and vegetables treated with Calactate are generally firmer than controls during storage (Suutarinen et al., 1999). Calactate $(0.5-2 \%)$ has been used as a firming agent for fruits such as cantaloupes, strawberry, and others (Morris et al., 1985). It has been reported to be a good alternative to calcium chlorine because it avoids the bitterness or off-flavours associated with this salt. The antibacterial properties of Ca-lactate washing solutions have been described for treatment of honeydew melon and minimally processed vegetables (Luna-Guzman and Barrett, 2000).

Heat-shock treatment, alone or combined with other agents (organics acids, etc.) have also been used to prevent browning reactions in various vegetables and fruits. 
Firming effects obtained from heat treatments alone or combined with Ca-lactate treatments has been attributed to the action of heat-activated pectin methyl esterase (PME) and/or to increased Ca-lactate diffusion into tissues at higher temperatures. In 2001, gaseous and aqueous (dissolved) $\mathrm{O}_{3}$ was approved by the U.S. Food and Drug administration for application as an antimicrobial agent to foods (FDA 2001). Research and commercial applications have indicated $\mathrm{O}_{3}$ as a suitable alternative sanitizing agent to chlorine. However, limited studies have been performed to determine the efficacy of $\mathrm{O}_{3}$ as a disinfectant in the fresh-cut produce industry. Whey protein concentrate is very popular in the food ingredient industry, however the use of whey permeate, consisting mainly in a solution of ashes and soluble nitrogen (biopeptides), is not so popular despite some interesting characteristics of it, e.g. low $\mathrm{pH}$ or bacteriocine content.

The objective of this study is to develop novel alternative decontaminating methods to extend minimally processed vegetable shelflife, especially salad-cut lettuce and sliced carrots.

\section{MATERIALS AND METHODS}

Iceberg lettuce (Lactuca sativa sp.) and carrot (Daucus carota sp.) were grown in Ireland and purchased from a local supermarket (Dunnes Stores, IRELAND) and stored at $4{ }^{\circ} \mathrm{C}$ until used. Different novel washing treatments were examined. Processed Iceberg lettuce (salad- cut lettuce) and (sliced) carrots were dipped in Ca-lactate $\left(0.5-3 \%\right.$ at $4{ }^{\circ} \mathrm{C}$, $25^{\circ} \mathrm{C}$ or $\left.50{ }^{\circ} \mathrm{C}\right), \mathrm{O}_{3}\left(1 \mathrm{ppm}\right.$ at $\left.25^{\circ} \mathrm{C}\right)$, whey permeate (WP) $\left(0.5 \%-1.5 \%\right.$ at $\left.25^{\circ} \mathrm{C}\right)$ and chlorine $\left(\mathrm{NaOCl}\right.$ solution with $120 \mathrm{ppm}$ free chlorine at $\left.25^{\circ} \mathrm{C}\right)$ for 1 minute in constant agitation. The processed vegetables were packaged and stored at $4{ }^{\circ} \mathrm{C}$ over 10 days. Headspace gas composition, exudate (Carlin and Nguyen-the 1999), dry matter, total carotenoids (Gross, 1991) and ascorbic acid (AOAC, 1995) were measured. Enzymes involved in browning Polyphenol oxidase (PPO) (Tan and Harris, 1995) and Peroxidase (POD) were measured spectrophotometrically. Colour parameters (CIE Lab*) were quantified using a colorimeter (ColorQuest XE) and digitally-obtained images, processed with Adobe Photoshop ${ }^{\circledR}$. Texture properties were measured with an Instron Universal Testing (Instron 4302 Universal Testing Machine, Canton MA, USA) and Pectin methyl esterase (PME) activity was quantified (Kimball, 1991). Appearance, aroma, mouth-feel texture, taste and overall acceptability of samples were scored on a hedonic scale of 1 to 5. The sensorial analysis was carried out with Compusense ${ }^{\circledR}$ Five (Release 4.4, Ontario, Canada). For microbiological studies 10 gram of vegetable was homogenised in $90 \mathrm{~mL}$ of peptone saline with a Stomacher circulator homogenizer. Enumeration and differentiation of microorganism were carried out as follows: mesophilic aerobic bacteria were quantified at $30{ }^{\circ} \mathrm{C}$ in plate count agar (PCA) over 72 hours. Psychrophilic bacteria were quantified in plate count agar (PCA) at $21^{\circ} \mathrm{C}$ over 25 hours. Enumeration of lactic acid bacteria was carried out using DeMan rogosa sharpe agar (MRS) at $35^{\circ} \mathrm{C}$ over 48 hours. Two independent runs were performed to analyse the effects of chlorine and Ca-lactate. All assays were carried out in duplicate.

\section{RESULTS}

\section{Ca-lactate (3\%) and Sodium Hypochlorite (120 ppm)}

Salad-cut lettuce and sliced carrots were washed with $3 \%$ Ca-lactate and with 120 ppm Chlorine, both treatments at room temperature $\left(25^{\circ} \mathrm{C}\right)$. The respiration rate was significantly $(p<0.05)$ higher in sliced carrots than in salad-cut lettuce during the storage. The vegetables treated with Ca-lactate had higher values of $\mathrm{CO}_{2}$ at the end of the storage although not significant $(\mathrm{p}>0.05)$, meanwhile the $\mathrm{O}_{2}$ levels did not show differences between treatments.

Ca-lactate reduced significantly $(p<0.05)$ the bleaching on salad-cut lettuce and sliced carrots and white surface appearance on sliced carrots (based on luminosity values) compared with chlorine. However, total colour change $(\Delta \mathrm{E})$ did not show significant differences between chlorine and Ca-lactate treatments on both vegetables (Fig. 1). 
Ca-lactate maintained the ascorbic acid in the same ranges that chlorine and enhanced the carotenoid content in sliced carrot, where the samples treated with Calactate had significantly $(\mathrm{p}<0.05)$ higher values $(9.70 \mathrm{mg} / \mathrm{g})$ than chlorine samples $(7.70$ $\mathrm{mg} / \mathrm{g}$ ) at the end of the storage.

PME, enzyme involved in pectin binding and textural changes, was evaluated in salad-cut lettuce and sliced carrots over 10 storage days. PME activity did not show significant differences between treatments for either vegetable $(p<0.05)$. These results were in agreement to the findings of the sensory panel and the texturometer results which did not show differences $(p>0.05)$ in texture between treatments.

Browning-related enzymes (PPO and POD) were monitored in salad-cut lettuce and sliced carrots. In salad-cut lettuce the chlorine treated samples had significantly $(p<0.05)$ higher POD activity values compared to Ca-lactate samples, effect not observed with the sliced carrots. PPO activity was significantly $(\mathrm{p}<0.05)$ higher in both vegetables when treated with Ca-lactate compared with chlorine. Although PPO is an enzyme directly related to browning, its activity is limited by the oxygen availability and is also influenced by peroxidase activity. Thus, although PPO activity value was higher in both vegetables treated with Ca-lactate, there were no significant $(\mathrm{p}>0.05)$ differences in visual browning (colorimeter measurements and sensory analysis).

The microbial load in salad-cut lettuce and sliced carrots (mesophiles, psychophiles and acid lactic bacteria) did not show significant $(p<0.05)$ differences between treatments during the storage (Fig. 2). No different efficacy after the treatment was due to the treatment and the values reached were very similar at the end of the storage.

\section{Ca-lactate Response Surface Study}

After the initial results indicating that Ca-lactate had potential as a disinfectant, it was tested over a range of temperatures $\left(4-50^{\circ} \mathrm{C}\right)$ and concentrations $(0.5-3 \%)$ in order to optimise the best conditions for use.

Ca-lactate concentration significantly $(p>0.05)$ affected $\mathrm{O}_{2}$ levels but not $\mathrm{CO}_{2}$ throughout the storage period. Samples treated with higher Ca-lactate concentrations at all temperatures presented significant $(\mathrm{p}>0.05)$ higher $\mathrm{O}_{2}$ concentration inside the bag. These results are in agreement with other authors who suggest that $\mathrm{Ca}$-lactate can reduce the respiration of minimally processed fresh vegetables.

The use of high treatment temperature $\left(50{ }^{\circ} \mathrm{C}\right)$, heat-shock, showed a positive effect on enzymes involved in quality maintenance. Heat-shock reduced significantly $(p<0.05)$ the activity of the enzymes PPO (Fig. 3) and POD, compared with $4{ }^{\circ} \mathrm{C}$ and 25 ${ }^{\circ} \mathrm{C} ; 50{ }^{\circ} \mathrm{C}$ increased significantly $(\mathrm{p}<0.05)$ the activity of PME (Fig. 4). When PPO activity values were correlated with results of colour analysis (appearance of browning), it was observed that lettuce treated at $50{ }^{\circ} \mathrm{C}$ showed significantly $(\mathrm{p}<0.05)$ lower levels of browning (lower $\mathrm{a}^{*}$ ). High Ca-lactate concentrations (3\%) produced a loss of luminosity $\left(\mathrm{L}^{*}\right)$ and greenness $\left(-\mathrm{a}^{*}\right)$. The use of high temperatures and intermediate Ca-lactate concentrations $(1.5 \%)$ proved to be the best washing treatment to maintain the quality of salad-cut lettuce over 10 days of storage.

These conditions $\left(50{ }^{\circ} \mathrm{C}\right.$ and $1.5 \%$ Ca-lactate) gave higher freshness and lower browning scores than chlorine $(120 \mathrm{ppm})$ treatment when evaluated by the sensory panel.

\section{Ca-lactate $\left(1.5 \%, 50{ }^{\circ} \mathrm{C}\right), \mathrm{O}_{3}\left(1 \mathrm{ppm}, 25^{\circ} \mathrm{C}\right)$ and Both Methods Combined}

Previous work reported the combination of high temperature $\left(50{ }^{\circ} \mathrm{C}\right)$ and $1.5 \%$ Ca-lactate showed the best conditions in order to extend the quality and shelf-life of fresh-cut vegetables. This washing treatment was compared with $\mathrm{O}_{3}(1 \mathrm{ppm})$ and the combination of both treatments together.

The $\mathrm{O}_{2}$ concentration in salad-cut lettuce packages was significantly $(p>0.05)$ higher when the samples were treated with $\mathrm{O}_{3}$ than with $\mathrm{Ca}$-lactate or the combined treatment $(\mathrm{p}<0.05)\left(\right.$ Fig.5). The $\mathrm{CO}_{2}$ increased significantly $(\mathrm{p}>0.05)$ in all the samples during storage with no differences between treatments. When using $\mathrm{O}_{3}$ (alone or 
combined with Ca-lactate) significantly $(\mathrm{p}<0.05)$ lower enzymatic activity was found (browning-related PPO and POD and texture-related PME) (Fig. 6).

The combined treatment $\left(\mathrm{O}_{3}\right.$ and $\mathrm{Ca}$-lactate $)$ produced a significant $(\mathrm{p}<0.05)$ increase in colour change on the samples compared to single treatments. The three different treatments were also evaluated by a sensory panel, and the scores for appearance, browning, odour, texture and general acceptability showed a significant variation during the storage $(\mathrm{p}<0.05)$. Browning perception increased and appearance, acceptability, fresh odour and crispy texture scores decreased during the storage. The panellist did not find differences between treatments.

Better texture results (higher PME activity and lower load in texture tests) and lower respiration rates were obtained in samples treated with Ca-lactate. $\mathrm{O}_{3}$ (alone or combined) treatments were more efficient in reducing browning-related enzyme activities; however the total colour change was higher with the combined treatment, probably due to the higher stress (two washing steps). Sensory panel did not find differences in fresh appearance between treatments.

\section{Whey Permeate $(0.5,1.5$ and $3 \%)$ and Chlorine (120 ppm)}

$\mathrm{WP}$ at different concentrations $(0.5,1.5$ and $3 \%)$ was compared with chlorine $(120 \mathrm{ppm})$ as decontamination washing treatments on salad-cut lettuce and sliced carrots. Package headspace gas $\left(\mathrm{O}_{2}\right.$ and $\left.\mathrm{CO}_{2}\right)$ concentrations were not significantly different $(\mathrm{p}>0.05)$ for salad-cut lettuce and sliced carrots washed with chlorine or WP (Fig. 7). A significant $(\mathrm{p}<0.05)$ effect in reducing browning with $3 \% \mathrm{WP}$ was found for both vegetables.

Nutritional markers, ascorbic acid and carotenoids, were tested during all the storage. In both vegetables, ascorbic acid decreased significantly $(p<0.05)$ during the storage with no differences due to treatment. However, significantly $(p<0.05)$ lower carotenoid content was found in samples treated with chlorine and $3 \%$ WP than in those treated with $0.5 \%$ and $1.5 \% \mathrm{WP}$.

The sensory panel considered all the samples of fresh-cut lettuce acceptable, irrespective of the treatment. However, in sliced carrots the sensory panel scored $3 \% \mathrm{WP}$ and chlorine treated carrots significantly $(p<0.05)$ less acceptable due to the high surface whiteness. Sensory panellists did not perceive cheese-like in any of the WP treated vegetable.

$3 \%$ WP resulted in equivalent or better microbial reduction than chlorine. Although lower concentrations of whey permeate produced minor initial reduction, microbial counts at the end of the storage were below the recommended levels $\left(10^{8}\right.$ $\mathrm{CFU} / \mathrm{g}$ ) for safety of fresh-cut vegetables.

\section{DISCUSSION}

New legislation limiting the use of chlorinated products has produced the need of novel alternative decontamination method development for fresh-cut vegetables. Together with a certain improvement in the safety of these products, disinfection processes are expected to maintain fresh attributes of the product. A special consideration is the browning, process associated to the loss of acceptability by consumers in lettuce. Calactate, $\mathrm{O}_{3}$, WP and heat-shock treatments among others are being investigated in the Postharvest Technology Unit.

Calcium lactate is a suitable washing treatment for salad-cut lettuce and sliced carrots. It has a similar antimicrobial effect to chlorine rinsing treatments and similar effects on several quality and nutritional parameters. It has advantages over chlorine in certain areas. Ca-lactate washing treatments avoid the post-treatment bleaching effect in salad-cut lettuce and the appearance of whiteness on surfaces of sliced carrots. Ca-lactate treatment, compared with chlorine, maintained similar or even better nutritional value of the samples during storage.

Browning and the loss of crispy texture are two of the most important causes of losses for fresh-cut vegetables in the market. An optimisation study of Ca-lactate 
treatment focused in these two quality parameters concluded $50{ }^{\circ} \mathrm{C}$ and $1.5 \%$ the best conditions of the study to extend the quality of fresh-cut vegetables.

$\mathrm{O}_{3}$ treatment (alone or combined with Ca-lactate) was more efficient in reducing browning-related enzyme activities than Ca-lactate. Total colour change was higher with the combined treatment, probably due to the higher stress (two washing steps). The sensory panel did not find significant differences in fresh appearance between treatments. In 10 storage days, Ca-lactate showed better quality indicators than either $\mathrm{O}_{3}$ and $\mathrm{O}_{3}$ combined with Ca-lactate. Perhaps longer storage times are needed to show quality differences (browning, total colour change) based on the enzymatic activity reduction of the $\mathrm{O}_{3}$ treatments.

Whey protein concentrate is widely used as ingredient in the food industry mostly because of its functional properties (emulsifying, foaming, and solubility) and high nutritional value (protein and mineral source). However, another dairy industry subproduct, the whey permeate, is discarded due to its low nutritional value (protein content), although an acid $\mathrm{pH}$ and bactericidal properties make it a potential decontamination agent. WP showed good antimicrobial activity when used as a wash treatment for sliced carrots and salad-cut lettuce. This antimicrobial effect may be due to the low $\mathrm{pH}$ of washing treatment, which might produce a protonation of cell components in the contaminating bacteria leading to inhibition of their growth. This helps to change the vegetable surface charge to a more positive value and thus increase the inhibition of bacterial growth throughout the entire storage period. The concentration of WP was an important factor in the control of microbial growth. Another explanation of the antimicrobial phenomenon could be associated with the presence bacteriocins in the WP and other small bio-active peptides, which are thermoresistant. Quality parameters in saladcut lettuce did not show differences between different WP treatment concentration and this was corroborated by the sensory panel data. Higher concentrations of WP gave a higher inhibition of browning-related enzymes. This indicates that perhaps $3 \% \mathrm{WP}$ wash treatment allows a longer storage of salad-cut lettuce. In sliced carrots $1.5 \%$ WP showed better efficacy than $3 \%$ WP in maintaining quality parameters.

\section{CONCLUSIONS}

The main conclusion is that Ca-lactate at $50{ }^{\circ} \mathrm{C}$ and $\mathrm{WP}$ are promising washing treatments for decontamination of fresh-cut vegetables although further investigations are needed in order to optimise them in terms of shelf-life, nutritional value, safety and quality.

\section{ACKNOWLEDGEMENTS}

The authors would like to acknowledge the financial support of the Technological Sector Research (2002-2006) and Glambia Ltd Ingredients for providing whey permeate.

\section{Literature Cited}

An Bord Glas http://www.bordglas.ie/facts/production.htm (accessed on $20^{\text {th }}$ March 2002).

AOAC. 1995. Official methods of analysis (16th ed.). Washington, DC: Association of Official Analytical Chemists.

Carlin, F. and Nguyen-the, C. 1999. Minimally processed produce microbiological issues. Proceedings of International Conference on Fresh-Cut Produce. Campden and Chorleywood, U.K.

Garret, E.H. 2002. Fresh-cut product: tracks and trends. In: Lamikanra O., editor. Freshcut fruits and vegetables. Science, technology and market. Boca Raton, Fila.:CRC Press. p. 1-10.

Gross, J. 1991. Carotenoids. In Pigments in Vegetables: Chlorophyllase and Carotenoids, Van Nostrand Reinhold, New. York. p.100.

Kimball, D.A. 1991. Citrus processing-quality control and technology. Van Nostrand Reinhold, New. York. p. 117-243. 
Luna-Guzman, I. and Barrett, D.M. 2000. Comparison of calcium chloride and Ca-lactate effectiveness in maintaining shelf stability and quality of fresh-cut cantaloupe. Postharvest Biol. Technol. 19:61-72.

Morris, J. R., Sistrunk, W.A., Sims, C.A., Main, G.L. and Wehunt, E.J. 1985. Effects of cultivar, postharvest storage, pre-processing dip treatments and style of pack on the processing quality of strawberries. J. of Amer. Soci. of Horti. Sci. 110, 172-177.

Singh N., Singh R. K., Bhunia A. K.and Stroshine R. L. 2002. Efficacy of chlorine dioxide, $\mathrm{O} 3$, and thyme essential oil or a sequential washing in killing escherichia coli o157:h7 on lettuce and baby carrots . Lebensm.-Wiss. u.-Technol. 35:720-729.

Suutarinen, J., Anakainen, L. and Autio, K. 1999. Comparison of light microscopy and spatially resolved Fourier transform infrared (FT-IR) microscopy in the examination of cell wall components of strawberries. Lebensm.-Wiss. u.-Technol. 31, 595-601.

Tan, B.K. and Harris, N.D. 1995. Food Chemistry. Maillard products inhibit apple polyphenoxidase. 53: 267-273.

Wei, C.I., Huang, T.S., Kim, J.M., Lin, W.F., Tamplin, M.L and Bartz, J.A. 1999. Growth and survival of Salmonella montevideo on tomatoes and disinfect ion with chlorinated water. Journal of Food Protection. 58: 829-836.

\section{Figures}

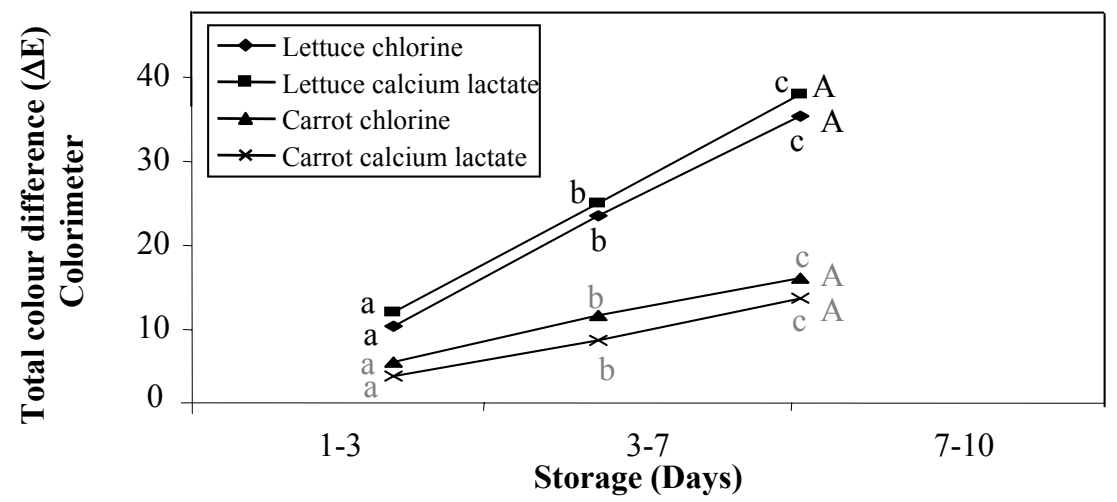

*Points designated by the same letter are not significantly different $(\mathrm{p}<0.05)$. Lower case letter are used for comparisons during the storage and upper case letter for treatment comparisons.

Fig. 1. Variation of colour during storage at $4{ }^{\circ} \mathrm{C}$ for salad-cut lettuce and salad-cut carrots treated with $120 \mathrm{ppm}$ chlorine and $3 \%$ Ca-lactate washing treatments. 
(i)
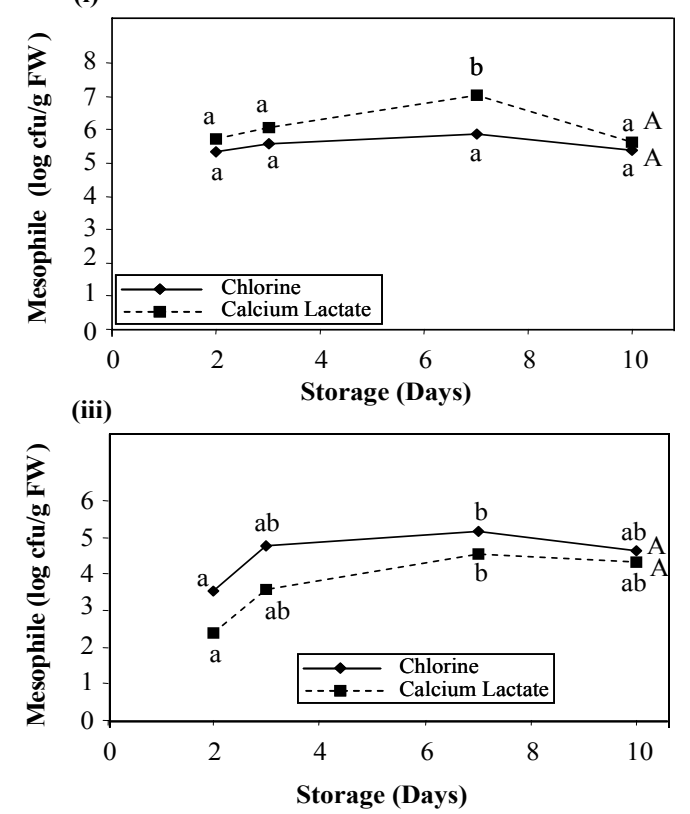

(ii)
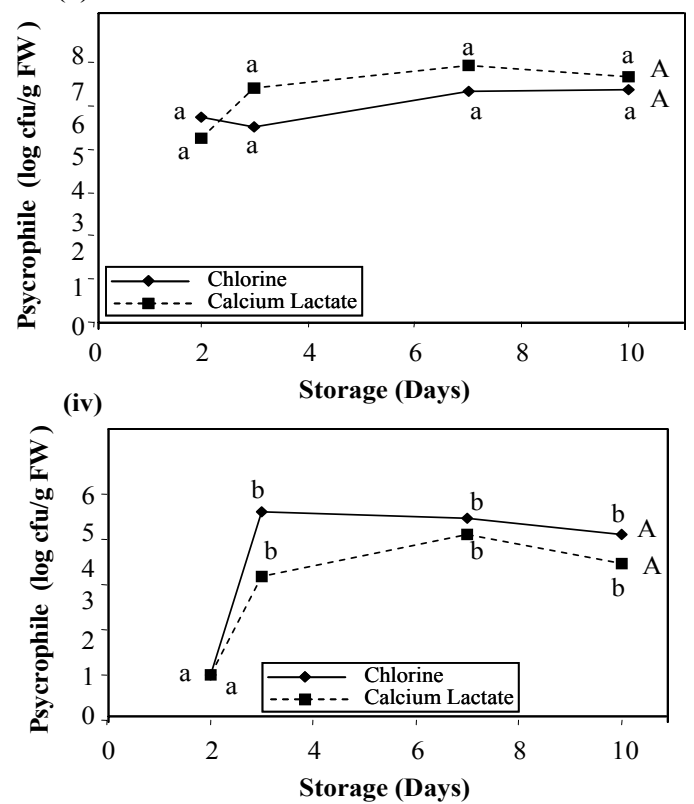

*Points designated by the same letter are not significantly different $(\mathrm{p}<0.05)$. Lower case letter are used for comparisons during the storage and upper case letter for treatment comparisons.

Fig. 2. Survival of microorganisms during storage of minimally processed salad-cut lettuce (i and ii) and sliced carrots (iii and iv) washing with $120 \mathrm{ppm}$ chlorine and $3 \%$ Ca-lactate over 10 storage days.

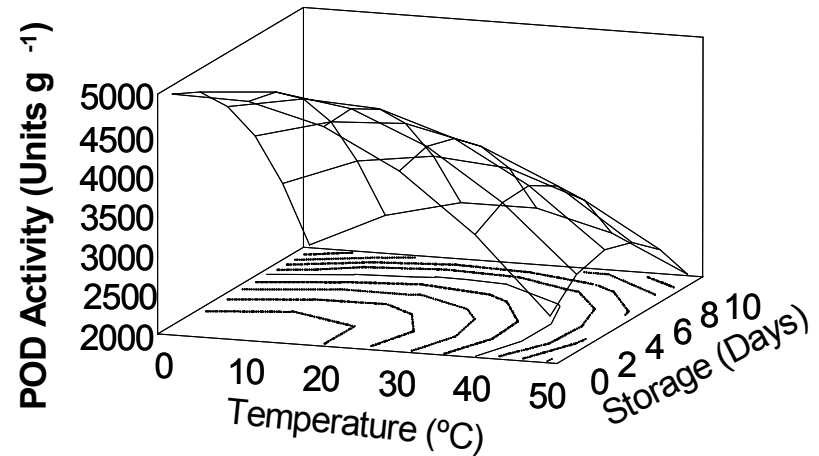

Fig. 3. Changes in polyphenol oxidase (PPO) activity as a function Ca-lactate concentration (\%) and storage time (days) for three different temperatures: (A), $4{ }^{\circ} \mathrm{C}$; (B), $25^{\circ} \mathrm{C}$ and (C), $50^{\circ} \mathrm{C}$. 


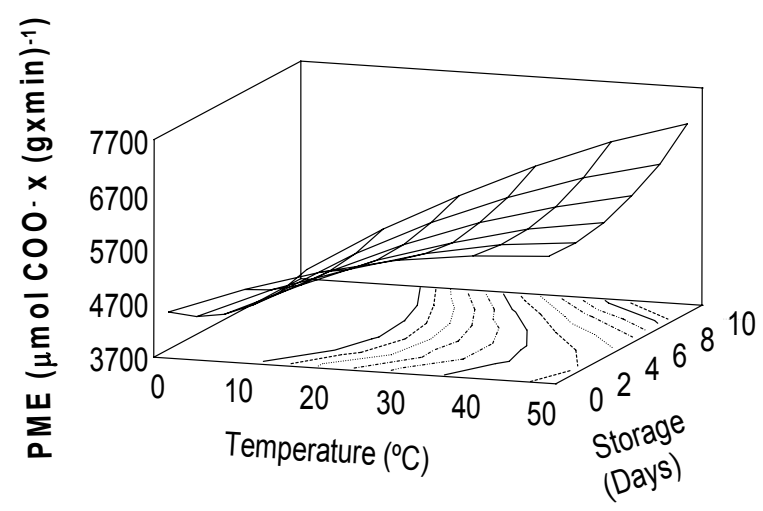

Fig. 4. Effect of temperature in the activity of pectin methyl esterase (PME) over the storage period.

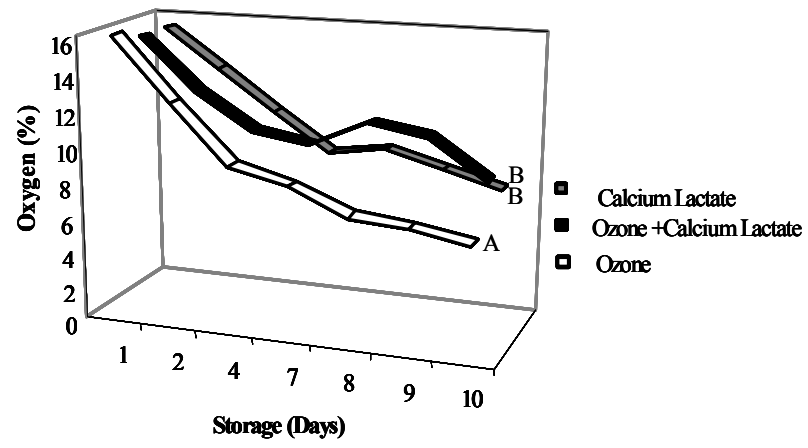

*Points designated by the same letter are not significantly different $(\mathrm{p}<0.05)$.

Upper case letter for comparison of treatments.

Fig. 5. Headspace $\mathrm{O}_{2}$ concentrations for samples treated with $1.5 \%$ Ca-lactate at $50{ }^{\circ} \mathrm{C}, 1$ ppm $\mathrm{O}_{3}$ at room temperature and the combination of both methods during all the storage.

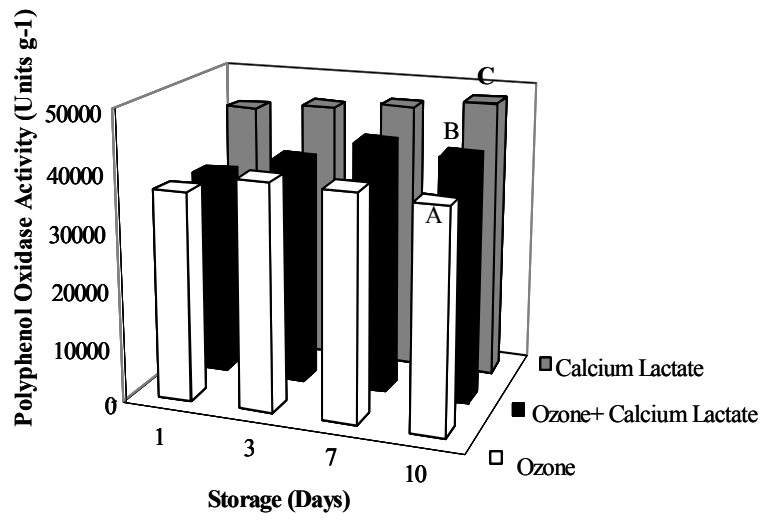

*Points designated by the same letter are not significantly different $(\mathrm{p}<0.05)$. Upper case letter for comparison of treatments.

Fig. 6. Polyphenol oxidase activity (PPO) after the treatment for samples treated with $1.5 \% \mathrm{Ca}$-lactate at $50^{\circ} \mathrm{C}, 1 \mathrm{ppm} \mathrm{O}_{3}$ at room temperature and the combination of both methods. 


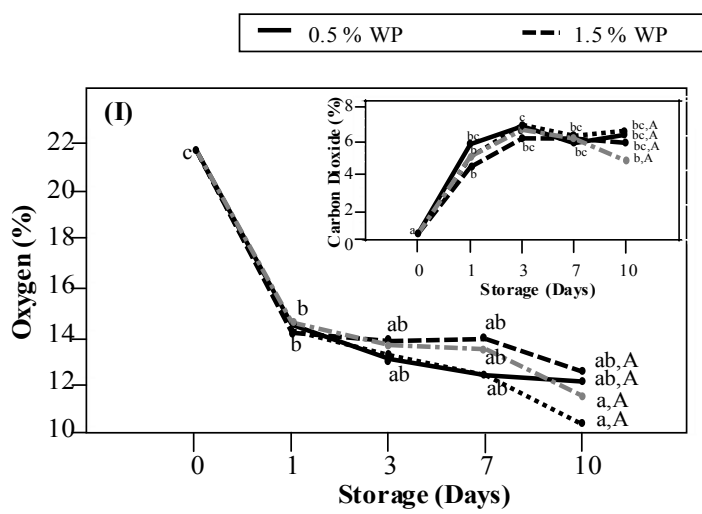

$\cdots 3.0 \%$ WP $\quad-\cdots$ CHLORINE

*Points designated by the same letter are not signific antly different $(\mathrm{p}>0.05)$. Lower case letter are used for comparisons during storage and upper case letter for comparison of treatments.

Fig. 7. Headspace $\left(\mathrm{O}_{2}\right.$ (I) and $\mathrm{CO}_{2}$ (II)) concentrations during the storage in lettuce and sliced carrots treated with $120 \mathrm{ppm}$ chlorine and whey permeate at different concentrations $(0.5,1.5$ and $3 \%)$. 
